\title{
Rethinking Migration-Development Nexus: A Case of Bangladeshi Migrants' Households
}

\author{
Munshi Israil Hossain* \\ *Assistant Professor, Department of Sociology, University of Rajshahi, Rajshahi-6205, Bangladesh
}

\begin{abstract}
This article aims to explicate the interactions between international labour migration and household development of migrants through the examination of empirical literature on migration in Bangladesh. The available data and information on migration and remittances suggest that the macro economy of Bangladesh has been considerably geared up by migrant workers' remittances. But the studies on migration have to a great extent overlooked to elucidate migration-development linkage in light of migrants' households. The article looks into some particular indicators of economic and social development of migrants' households while at the same time it explains some indicators that negatively impact on both the economic and social development, i.e. they contribute to stimulate underdevelopment of migrants' households. In order to understand the actual development, economically and socially, the analysis of this article bases the optimist, developmentalist and neoclassical, and pessimist, historical-structuralist and dependency approaches posed by Tylor and De Haas. It concludes proposing some recommendations for the researchers and then for the policymakers in order to ensure the development of migrants and their household members and the country as a whole.
\end{abstract}

Keywords: Bangladesh, Development, Household, Migration

\section{Introduction}

Time and space determine the diversified reasons of migration, types of migration and thereby the consequences of migration. However, the present globalisation period stimulates those people, economic migrants ${ }^{1}$, who want to make a living. The main aim of making a living is to develop economic and social conditions particularly of migrants' households, and then the community and the country. In order to do so, people moved across the globe during the colonisation, post colonisation and industrialisation periods but migration in globalisation period has marked a special attention to all walks of people especially to those researchers, academics and policymakers all over the world who are keen to understand the impacts of migration. To better understanding the true impacts of migration on economic and social developments globally many studies have been conducted on migration. It is evident that most of studies to a great extent have rigorously investigated the impacts of remittances on national economy while these studies have lightly explored and analysed the economic development of migrants' households and the community as a whole.

Developmental impacts of migration at the national level of origin countries is clearly and positively established but at the household level it faces a serious challenge by a school of thought due to its complex and interdependent nature (IOM, 2003; Morrison \& Sinkin, 1982) because one affects and is affected by other (IOM, 2003 \& 2006; Lucas, 2005). It is because migration is not only a cause of underdevelopment; it is also a result of underdevelopment. Further, the increasing South-North development gap has made migrationdevelopment interaction more complex (GCIM, 2005). As Ratha (2006) states, the participants of High-Level Dialogue highlight some significant positive impacts of international migration on social and economic development as well as some certain negative impacts as well. The relations and interrelationships in and between migration, remittances and development have made 'remittance euphoria' (De Haas, 2007). Until recently, migration-development relations have emerged as a much-talked issue not only for migration destination countries it has firmly established a pressing issue also for the welfare of migrants' households, communities and migrant sending countries like Bangladesh.

In order to better examining the migration-development nexus of migrants' households the article will first conceptualise the theoretical issue that is dominant in current migration field of the world, particularly the developmentalist and neoclassical as well as historical-structuralist and dependency approaches. It will then highlight the trend of migration and remittances in Bangladesh including the dynamics of remittances to the national economy of Bangladesh. The main focusing area of this article is to scrutinise migration-development interactions of migrants' household in light of the recent empirical literature on migration in Bangladesh. It will

\footnotetext{
${ }^{1}$ a person leaving his/her habitual place of residence to settle outside his/her country of origin in order to improve his/her quality of life
} 
finally draw attention to some specific policy issues and the directions for future research in order to exhaust the maximum benefits from migration.

\section{Theoretical Underpinnings}

Scholars from different disciplines view development from their own perspectives. Economists, for example, mainly focus on economic dimensions of development such as economic growth including some other indicators that also indicate income; sociologists and other social scientists focus on social dimensions of development such as health, education, employment, poverty, inequality etc. Sen is an economist but he (1999) proposes a comprehensive approach to development in terms of social indicator such as 'freedom' that people enjoy which is solely related to social development. He conceptualises 'freedoms' explaining the concept 'human capability' that is related to the ability of human beings to lead lives they have reason to value and to enhance their substantive choices. The basic assumption here is that the expansion of human capabilities accelerates the quality of people's lives. His understanding of development encompasses elements such as social well-being, poverty alleviation, income inequality, gender equality and universal access to primary education, health care and meaningful employment (Sen, 1999). While other disciples articulate a range of cultural and political dimensions of development. After all, all these dimensions are firmly interconnected because one influences and is influenced by other. The interconnections have made a notoriously difficult linkage between migration and development as well as made a contested theme.

The interaction between migration, remittances and development as well as its contested condition is a centre of attention particularly during this globalisation period (Tylor, 1999). In order to clarify and respond the nexus Tylor has divided migration-development impacts into two extremes. The first extreme is 'developmentalist' that argues that family is the basic unit to make migration decision in order to increase income as well as to reduce income and production risks (p.3). It also argues that family earns income not only to invest in new activities; remittances at the same time reduce production and investment constraints faced particularly by the migrants of poor country. On the other hand, the second extreme is 'Dutch disease' or 'migrant syndrome' (p.64) that argues that migrants' labour and capital are drained to labour receiving countries that contribute to decline local production of migrants. Tylor has regarded 'developmentalist' and 'migrant syndrome' extremes as optimist and pessimist approach, respectively.

Subsequently, De Haas (2007 \& 2010) has expanded both the approaches in terms of economic and social dimensions of development. He explains the first extreme, the optimist, as developmentalist and neoclassical approach that conceptualises international labour migration positively and suggests that it has a multidimensional contribution to migrants' households, communities and the countries of migrants as a whole. While the second extreme, the pessimist, as historical-structural and dependency approach that emerges in challenging optimist approach and views international labour migration negatively for migrants' households, communities and the origin countries of migrants. Haas (2007) has proposed third approach as pluralist (new economics of labour migration and livelihoods) that responds to the optimist and pessimist approaches and proposes that both approaches are so rigid and deterministic that they cannot deal with the realities of migration and development interactions but pluralist approach offers a much more comprehensive view of migration and development which does not only bridge the causes and consequences of migration explicitly but also it distinctively explores both the positive and negative consequences of migration and remittances.

Optimist and pessimist approaches are two dominant theoretical standpoints in migration literature which has clearly indicated to economic and social development as well as underdevelopment of migrants' households. In order to examine the household level impacts of migration and remittances it is worthwhile to scrutinise first the impacts of migration and remittances on the macro economy of Bangladesh which will make clear the developmental impacts of migration and remittances on migrants' households, the aim of this article.

\section{Migration and Remittances of Bangladesh}

The development of information technologies and communication systems across the world has significantly increased people's movement over the last few decades. But Asia has exceptionally witnessed the movement of its population in and outside Asia particularly due to the hike of oil price in some Middle Eastern economies in 1970s as well as to the introduction of export-led development strategy in some Southeast Asian economies in 1980s that transfer them capital-rich and labour-poor countries. On the other hand, the colonial and post-colonial social, economic and cultural construction as well as the rigidity in economic reformation and social problems after independence of South Asian countries has regarded them as capital-poor and labour-rich region. At the same time, regional social, economic, political and cultural cooperation and integration in and between Asian economies has reduced barriers to move from one country to another in Asia. Thus, the Middle Eastern and Southeast Asian countries have been regarded as the lands of remittances while South Asia has been regarded as a land of migrant workers. Bangladesh has emerged one of the potential labour-sending countries not only in South Asia but also in the world. 
In South Asia, Bangladesh is the second largest manpower exporting country, next to India. A cumulative total of 8.7 million Bangladeshis had travelled to more than 101overseas countries during 1976-2013 period in order to sustain and/or improve their livelihoods (BMET, 2014), making the country $7^{\text {th }}$ largest labour origin country of the world (World Bank, 2013). Migration literature also suggests that the people who have migrated officially, almost the equal number of Bangladeshis are migrating overseas through the unofficial channels (Siddiqui and Abrar, 2003). Out of official total migrants, more than 90\% are semi-skilled and unskilled, of whom more than $90 \%$ have migrated to the Middle Eastern and Southeast Asian countries (BMET, 2014).

The dynamics of migration and remittances is substantial to country's economic and social development from the beginning. In terms of economic development, remittances have increased significantly in recent times and become a second most important source of foreign exchange after the garment sector of Bangladesh (Chowdhury, 2010). As per most recent official records, Bangladesh earned more than USD12 and USD14 billion remittances during 2011 and 2012, respectively but it slightly dropped in 2013 due to political instability of Bangladesh (Bangladesh Bank, 2014). The volume of remittances would also be almost doubled if unofficial transfer of remittances counted (Siddiqui and Abrar, 2003).

As the volume of remittances has increased, the contribution of remittances to the national economy has been greater than before. There has been an exponential growth of Gross Domestic Product (GDP) and export earning since 1976 to the present. MoF (2012) reports that remittances contributed to GDP $3.74 \%$ and export earning 32.04\% in 1998-99 fiscal year while it was 7.75 and $45.62 \%$ in 2005-06 fiscal year. Further, both contributions increased and stood at $11.12 \%$ and $52.92 \%$ in $2011-2012$ fiscal years. Additionally, commercial service exports and merchandise exports are also heavily influenced by remittances which account for $1125 \%$ and 70\% in 2009, respectively (Migration Policy Institute, 2012). Moreover, the contributions of $13.68 \%$ GDP in 2011 has indicated 3.22 times higher than net income from apparel exports as well as 6.4 and 12.5 times higher than overseas development assistance and foreign direct investment, respectively (Siddiqui \& Billah, 2011). Also, remittances accounted for $95 \%$ of current transfers which were equivalent to $62 \%$ of exports and could finance $48 \%$ of the value of imports in 2009 (Bangladesh Bank, 2009). More interestingly, an increase in remittance by Taka 1 would result in an increase in national income by Taka 3.33 (Murshid et al., 2002). So, it can be said from the macro frontier that remittances are not only used to make import payments but also for productive investment by the government (Salim, 1992).

Aside from economic development, migration and remittances have contributed to improve social dimensions of development reducing unemployment (Rahman \& Rahman, 2000), increasing substantial employment in the country (Buchenau, 2008) and reducing poverty by as much as 6\% (Ratha, 2006). Thus, there has been direct and multiplier impacts of migration and remittances on the macroeconomics of Bangladesh. But what changes do migrants' households experience? Do the changes indicate economic or social development or both? Do the changes indicate economic or social underdevelopment or both? The investigation of these questions are considerably important because many studies on migration in Bangladesh have found a range of economic and social indicators of development while at the same time migrants' households face a range of problems that indicate economic and social underdevelopment. Due to this, migration-development nexus is similarly contested also in Bangladesh context like the global context. The next section of the article thus will mainly focus upon the role of migration and remittances how they have influenced on economic and social development and underdevelopment of migrants' households in Bangladesh in light of optimist and pessimist perspectives, explained before.

\subsection{Optimist Views: Developmentalist and Neo-classical}

The empirical literature on migration in Bangladesh has found a significant role in boosting national economy while at the same time the literature has explored the push-pull factors of migration and the consequences at the migrants' households and community levels. These studies have mainly given attention on the economic and social benefits of migration and remittances while some have also explained the economic and social costs/ramifications. This part of the article has synthesised the existing studies on migration and explained the findings in terms of the dimensions that accrue economic and social development i.e. through the optimist or developmentalist and neo-classical perspective.

In terms of economic development, a lion share of remittances is used for productive purposes, meeting basic needs and future insurance. Many studies have confirmed that migrants spend almost half of their remittances income on the purpose of purchasing arable land for cultivation (Mahmood, 1991; Rahman, 2000b; Siddiqui, 2001; Joarder \& Hasanuzzaman, 2008). In order to make an income a small group of returnee migrants have been able to invest remittances in small business in their local areas (Siddiqui and Abrar, 2003; Hossain et al. 2013); a few returnee migrants at the same time have established business in the city (Hossain et al. 2013). In addition, migrants are aware for their future that has inspired them to save money as well as buy bond and 
insurance (Siddiqui, 2001; Siddiqui \& Abrar, 2003). Apart from direct investment, remittances have indirectly contributed to economic development in generating income and employment (Murshid et al., 2002; Siddiqui \& Abrar 2001). Thus, productive and reproductive economic activities have increased income of migrants' households and secured their livelihoods too.

A significant amount of remittances are used in ensuring basic needs or quality of life. One-third of remittances are spent on family maintenances such as food and cloth (Rahman, 2000b \& 2012; Siddiqui, 2001; Siddiqui \& Abrar, 2003; Anh, 2003). To repair and make new houses for dwelling purpose is one of the important areas of spending money that meet basic need as well (Siddiqui, 2001 \& 2004; Afsar et al., 2002; UNDP, 2009; Rahman, 2012) while they also spend for medical treatment and education of their family members (Mahmood, 1991; Siddiqui \& Abrar, 2002; Rahman, 2012). Migrant families are more likely to send their children in school because they are capable of paying fees and other educational expenses for their children. Moreover, the rate of girls' education among the migrants' households is higher than non-migrants households because of cultural exchange like secular value which aspires and modifies the traditional cultural practice of dowry (Hadi, 2001). It is obvious that migrants' households possess a good quality of life as compared to those non-migrants households who had the same social and economic background before migration of the former group of households.

'Conspicuous consumption' and 'conspicuous generosity' is also equally important to enhance particularly the social quality life. Television and music items, for instance, for personal use is almost common to all the Bangladeshi migrants in Singapore and other Southeast Asian countries (Rahman, 2010; Hossain, 2010) while some also purchase gold ornaments and cosmetics for their family members and relatives (Rahman, 2004; Hossain, 2010) as well as donate a part of remittances to the poor and mosques, madaras, schools and colleges in the community (Hossain, 2010). To buy ornaments by many unmarried migrants in Singapore is interesting because they hope to get married a higher educated and beautiful bride after return home that brings and enhances social status of returnee migrants and their households (Rahman, 2004). All these expenditure and donations enhance social status and identity of migrants and their household members.

Gender relations are produced and reproduced by migration and remittances that empower of women, an indicator of social development. As Siddiqui and Abrar (2003) report, migration and thereby remittances income empower women migrants to negotiate with harsh work condition in developing certain independent decision making capacity. Moreover, overseas experiences teach women how to take decision in the crucial moment even in the case of divorcing their husbands when husbands alienate from their normal behaviours and activities (Rahman \& Rahman, 2000). Additionally, migration enables women migrants to be consciousness regarding their rights and lessons them how to negotiate in achieving human rights at home and abroad. The neglected women thus establish their positions in the family contributing remittances (Roy \& Nangia, 2002). Remittances and overseas exposure empower women migrants in taking decision in and outside households, even in some crucial moments.

The left behind wives of migrants are similarly empowered but in different ways. The wives of migrants can decide and participate in the decision-making processes that are higher than those of women in non-migrants households (Hadi, 2001; UNDP, 2009). Men's absence in the households has led some women to play a new role in male domain and as a result they become capable of making decision (Gardner, 1995) and the decision-making probability is 3.39 times higher compared to the wives of non-migrants where age, years of schooling, land ownership and religious beliefs of household members are controlled (Hadi, 2001). Women as left behind wives become empower because they receive and control remittances sent by their husbands and due to this they dominate to control over other resources of households. Also, they construct new relations outside the households giving migration information to friends and neighbours and helping them also giving money for migration, is regarded as a 'symbol of status' (Rahman, 2009). Like women migrants, migrants' wives establish a new position in and outside the household premises that empowers them and label them new social identity.

While at the same time other members of migrants' households enjoy some sorts of social opportunities that are beyond the traditional social boundaries is called 'migration capital' (Rahman, 2009:167). International migration is also a 'culture of honour' because migrants' households are recognised by new identity in the community as they are introduced as specific country by the neighbours such as Singapori bari (home), Malaysia bari etc., from where someone migrates. Cultural capital further increases because remittances empower migrants' fathers in the community and influence to take leadership as they have substantial economic solvency. Also, they are occasionally involved in political mobilization particularly at the union parishad (fourth level of local government) level by dint of 'migration capital' and remittances (Rahman, 2000a \& 2009). Like other household members, migrants themselves become influential persons/local leaders in school or college committees and local level administrative body after return from overseas (Afsar et al., 2002). Migration and remittances thus empower migrants' household members and enhance social position that contributes to expand social and cultural capital. 
Developmentalist and neoclassical approach of migration and remittances have thus paid attention upon the dimensions of economic and social development of migrants and their household members. In terms of economic development, a significant part of remittances are used in productive and reproductive activities such as land and business that have increased physical and financial resources. In case of social development, remittances are largely spent for food, education and health that have increased human capitals. Another important dimension of social development is that the decision-making capability of women migrants and the wives of male migrants. Furthermore, due to having valuable durables in the households and new social relations have lifted up social status and identity of migrants and other household members. Along with the economic and social developmental impacts the empirical studies on migration have also found a range of insights that have negatively influenced on economic and social aspects of development, is illustrated by historical-structuralist and dependency approach.

\subsection{Pessimist Views: Historical-Structural and Dependency}

While optimist views of migration and remittances have concentrated on economic and social development, pessimist views of migration and remittances have focused upon just the opposite aspects of optimist views. Migration literature has unearthed some insights that have significantly contributed to weaken economic and social conditions of migrants' households such as migration and remittances have contributed to: decline migrants' household income, increase unemployment and dependency, create conflict, and break down traditional headship and joint family, drop out children, diminish social status and identity, disempower women and affect by HIV/AIDS.

The main economic cost of migration is that the financial, physical and material resources of migrant households have reduced; thereby they have faced economic hardship particularly immediate after migration. As Rahman (2013) states, the economic costs of migration reduce regular family incomes and weaken the economic base of the family because expenditure for migration is solely arranged by selling valuable resources of household such as arable land, livestock, crops and ornaments. The outflows of family resources force the dependence of family economics upon migrant remittances. The heavily dependent on remittances for food, cloth, medical treatment and education has reduced the investment of remittances in economic venturesconstituting between 1 and $5 \%$ (USAID, 2007). Further, the economic cost of households has accelerated because of migration of able-bodied household members that has depleted labour in the village, reduced agricultural productivity (Ifran, 1986; Hossain et al., 2013) and eventually decreased household resources. The use of resources for migration as well as migration of younger people overseas has reduced household resources that have deteriorated their economic conditions.

Social costs/social ramifications are much more severe than economic costs. Unemployment and dependence is regarded as one of the most serious social costs. Because of regular inflows of remittances many members of migrants' households feel reluctant to work in the field, they become unemployed and dependent members in the households. Not only non-migrants in the households, migrants themselves have become unemployed and dependent members after their return home. Rahman (2000b) explicitly states that returnee migrants are evaluated negatively by the villagers if they work in the field on their own lands and/or other lands; instead, villagers think that the work in the field is for those villagers who do not get opportunity to go to overseas. The majority of returnee migrants feel apathy to work in the field in order to protect social status and as a result they become unemployed (Bruyn \& Kuddus, 2005; Hossain et al., 2013).

Familial clash and disharmony is another social cost. The control and use of remittances income by the migrants' wives divides the extended family and forms the nuclear one as well as transforms the 'traditional headship' to modern one (Siddiqui, 2001; Roy \& Nangia, 2002; Hossain et al., 2013). The economic power of migrants neglects the authority of old-aged people in the family that influences on the 'traditional family power structure' and transforms it into new power structure headed by migrants (Rahman, 2004). The breakdown of extended family and traditional power structure has in fact violated social norms and values that have led unhealthy family life.

Children's drop out and deviation from society is a serious social cost of migration. Migration of household head and/or any other important person stops to continuing study of younger family members because of lack of proper care and guidance (Hadi, 2001; Hossain et al. 2013). Many children particularly elder daughters of women migrants drop out schools as they take care of their younger siblings and do household activities in the absence of their mothers which migrants could do (Siddiqui, 2001). Elder sons of women migrants similarly look after their younger siblings, help their fathers in agriculture and drop out schools. Siddiqui (2001) also finds that few sons of women migrants are not only drop out schools they addict in drug as well.

In addition, migration of women creates a critical situation for all the household members. Siddiqui (2001) points out that gender division of labour becomes unchanged in the households because husbands of women migrants cannot play the same role that their wives did. Due to this, husbands of women migrants are 
often compelled to get married in order to look after children, older family members and household activities which usually break down the familial ties. Even few husbands get married their sons and daughters off at the early age to get relief from responsibility of taking care small children (Siddiqui, 2001). Women migration is a severe problem that generates uncongenial environment for all household members.

Migration of male members as well as the engagement of them and their wives in socially unacceptable behaviours and activities is the most serious social ramification. It is true that social mobility of left behind women increases due to move of various places for household purposes but at the same time they face serious social criticisms because the frequent move from households to outside of society is normally considered the break of established social norms and values. People do not only criticise women they even feel unwillingness to helping them in any problem. Because of the lack of social support as well as workload in and outside the household they feel extreme depression, insecurity and loneliness (Hossain et al., 2013). A few wives of migrants are involved in extramarital relationship in and outside the village and break up the family relationship (Afsar et al., 2002; Hossain et al., 2013). Additionally, women migrants are affected by HIV/AIDS in destinations while the left behind wives of male migrants are affected by their migrant husbands (Roy \& Nangia, 2002; Rahman \& Rahman, 2000). So, women suffer at all stages of social and economic life as being migrants and left behind wives.

Historical-structuralist and dependency approach has presented some specific aspects of economic and social life of migrants and their household members. Household resources do not only reduce they become less capable of mobilising resources that have influenced on other resources to reduce. Those who are success in migration they force their household members to be unemployed and dependence as they send remittances regularly and then migrants themselves become unemployed and dependence after their return home. The approach also finds that familial conflict and disharmony has emerged as a new fashion surrounding remittances, extramarital relationships and drugs. Most importantly, the young children have dropped out schools and colleges as well as deviated from society due to lack of proper guidance and care as well as also by their parents' unacceptable social activities and behaviours. Women as migrants and women as wives of migrants are harassed economically, socially, physically and mentally by themselves, their husbands and by the society where they live.

\section{Migration and Development: Issues for Rethinking}

The optimist and pessimist approaches have emphasised two opposite aspects of developmental impacts of migration and remittances on migrants' households. The only focusing area of optimist approach is to look into those dimensions that ensure economic and social development while the pessimist approach focus on those dimensions that diminish economic and social development. The contradictory impacts have jeopardised the developmental impacts on migrants' households and generated debate regarding migrationdevelopment nexus. Economic growth at the national level is clearly marked. It is also clear that a group of migrants' households are economically benefitted as their household income increases while it is equally true for some whose economy has deteriorated. Within this paradoxical situation it is notoriously difficult to conclude the developmental impacts of migration and remittances on migrants' households and for this the developmental impacts of migration on economic development has faced a serious question that needs to rethink.

Both approaches have again paid attention on social dimensions of development and underdevelopment. Parallel to economic development, the optimist approach has focused on social development that is similar to Sen's concept 'human capability'. Human capabilities of migrants' household members have increased than those of non-migrants' household members due to increase household income while human capability indicators or the indicators of social development has worsened of some migrants and their household members due to reduce household resources. Employment status and independency as well as unemployment status and dependency of migrants' household members are another indicator of social development and underdevelopment. Thus, migration and remittances have enhanced social development or human capability indicators of some migrants' household members and diminished others; claim to elucidate the migrationdevelopment interactions.

Social construction of gender relations is the most important dimension that directly impacts on social development and indirectly impacts on economic development. As of optimist approach, women migrants and the left behind wives of male migrants have been able to make decision, even in some critical situation, another important dimension of social development, as the former group of women earns income and contributes to households and the later group receives, controls and uses remittances sent by their husbands. It is equally true, as of pessimist approach that the movement of wives of migrants have limited and faced social criticism as their frequent movement outside the households. In some cases, women themselves are responsible to make their freedom confined in the household ground due to their socially unacceptable behaviours and activities. The violation of socially established norms and values by the wives of migrants and children has negatively changed 
social relations in and between household that has reduced social and cultural capitals, and finally worsened social life. Thus, the socially constructed dimensions of development and underdevelopment have contested the developmental impacts of migration and remittances that requires revisit.

The income growth of a country that is stimulated by remittances is not the only indicator of development. Along with the macroeconomic development it is significantly important to assess the income of those migrants' households who contribute to gear up the macro economy of the country working hard overseas and sending remittances home. Economic development of a household is a part of complete development. The complete development, economic and social ${ }^{2}$, is only possible when the household economy of migrants increases while at the same time increases of social dimensions of development. Thus, in order to explicate the holistic development of migrants' households it is imperative to take into account economic and social costs and benefits and it is simultaneously worthwhile to eradicate all sorts of economic, social and cultural difficulties that migrants and their household members encounter in and outside the households.

\section{Concluding Remarks}

This article has aimed to explicate the effects of migration and remittances on economic and social development of migrants' households through the lens of Tylor's and De Haas's optimist and pessimist approaches. In so doing, it has examined the empirical literature on migration in Bangladesh and understood that the impacts of migration and remittances on migrants' households are so diversified that it is notoriously difficult to gauge the developmental impacts.

The discourse has made it clear in the context of optimist approach that migration and remittances have improved some economic and social aspects of development increasing migrants' economic, material, physical and social resources that have contributed to sustain households' incomes and livelihoods. On the contrary, the pessimist approach has indicated that migrants and their household members have experienced a range of economic and social problems that have negatively impacted on their income and livelihoods. The problems they have faced that contributed to strengthen underdevelopment reducing financial, material, physical and social resources and thereby the incomes and livelihoods of a group of migrants have become unsustainable. So, it can be said that the pluralist view that Tylor suggested is much more suitable to understand the developmental impacts of migration and remittances on migrants' households because it pays attention on both the costs and benefits of migration and remittances in light of migrants' livelihoods.

The article suggests that the researchers and the policymakers can take some strategies to ensure the holistic development of migrants' households and the country as a whole. The researchers can design migration studies in such a way that they can unfold the external and internal factors of political-legal, economic, socialcultural and technological (PEST analysis) that influence on developmental impacts of migrants' households. Also, they can measure the true development exploring the strengths, weaknesses, opportunities and threats (SWOT analysis) of external and internal factors. On the other hand, the policymakers can take insights from the researchers and promulgate migrant-friendly policies that encompass the grassroots people. It is because migration policies and laws of Bangladesh merely reflect the social, economic, cultural, legal and political factors of grassroots people.

\section{References}

[1]. Afsar, R., Yunus, M., \& Islam, A. S. (2002). Are Migrants Chasing After the" golden Deer"? A Study on Cost-benefit Analysis of Overseas Migration by the Bangladeshi Labour: International Organization for Migration (IOM), Regional Office for South Asia.

[2]. Ahmed, H. A., \& Uddin, M. G. S. (2009). Export, Imports, Remittance and Growth in Bangladesh: An Empirical Analysis. Trade and Development Review, 2(2).

[3]. Anh, D. N. (2003). Migration and poverty in Asia: with reference to Bangladesh, China, the Philippines and Viet Nam. Paper presented at the Conference proceedings: Ad Hoc Expert Group Meeting on Migration and Development, Organised by the Economic and Social Commission for Asia and the Pacific.

[4]. Bangladesh Bank (2014). Annual Report 2012-13. Bank and Financial Institutions Division. Dhaka

[5]. Bangladesh Bank (2009). Macroeconomic policy challenges of large remittance inflow. Paper presented at the Strengthening Remittance Flows and Impact: Policies, Practice, Prospects, Istanbul Congress Centre, Session II.

[6]. Bruyn, T. D., \& Kuddus, U. (2005). Dynamics of Remittance Utilization in Bangladesh, IOM Migration Research Series, Regional Office for South Asia. International Organization for Migration, Geneva.

[7]. Buchenau, J. (2008). Migration, remittances, and poverty alleviation in Bangladesh report and proposal. United Nations Development Program, Dhaka Bangladesh.

[8]. Bureau of Manpower, Employment and Training (BMET). (2014). Overseas Employment and Remittances from $1976-2013$. Retrieved 21th March 2014 http://www.bmet.gov.bd/BMET/viewStatReport.action?reportnumber=31

[9]. Chowdhury, M. B. (2011). Remittances flow and financial development in Bangladesh. Economic Modelling, 28(6), 2600-2608.

[10]. De Haas, H. (2007). Remittances, migration and social development. UNRISD Programme paper (34).

[11]. De Haas, H. (2010). Migration and development: a theoretical perspective1. International Migration Review, 44(1), $227-264$.

[12]. Gardner, K. (1995). Global Migrants, Local Lives: Travel and Transformation in Rural Bangladesh: Travel and Transformation in Rural Bangladesh: Oxford University Press.

${ }^{2}$ Social development includes social, cultural and political dimensions. 
[13]. Global Commission on International Migration (GCIM). (2005). Migration in an Interconnected World: New Directions for Action: The Commission.

[14]. Hadi, A. (2001). International migration and the change of women's position among the left-behind in rural Bangladesh. International Journal of Population Geography, 7(1), 53-61.

[15]. Hossain, M. I. (2010). Subjective Well-being of the Migrants' Family Members of Rural Bangladesh: A Case Study of a Bangladeshi Village. Social Science Journal, 14, 119-134.

[16]. Hossain, M. I., Khan, M. A., \& Short, P. (2013). Migration of Bangladeshi workers to Malaysia: emerging lessons of economic and social costs and benefits at the migrant, migrant household and community levels. The Asian Century, Sustainable Growth and Climate Change, 2013. Edward Elgar Publishing

[17]. International Organization for Migration (IOM). (2003). Data on Migration and Development: IOM Data and Workshop, 8-9 September.

[18]. International Organization for Migration (IOM). (2006). The High-Level Dialogue on International Migration and Development. http://www.un.int/iom/IOM-HLD.html Retrieved 5th August, 2010

[19]. Irfan, M. (1986). Migration and Development in Pakistan: Some Selected Issues. The Pakistan Development Review, 743-755.

[20]. Joarder, M. A. M., \& Hasanuzzaman, S. (2008). Migration decision from Bangladesh: permanent versus temporary. Asia Europe Journal, 6(3-4), 531-545.

[21]. Lucas, R. E. (2005). International migration and economic development: Lessons from low-income countries: Edward Elgar Publishing.

[22]. Mahmood, R. A. (1991). Bangladeshi returned migrants from the Middle East: Process, achievement and adjustment. Migrants to the Arab world: Experiences of the returning migrants, 238-289.

[23]. Migration Policy Institute (2012). Remittance Profile of Bangladesh. Retrieved 5th January 2013

[24]. Ministry of Finance (MoF). (2009). Bangladesh Economic Review 2009. Bangladesh Bureau of Statistics. Dhaka. Bangladesh

[25]. Ministry of Finance (MoF). (2012). Bangladesh Economic Review 2012. Bangladesh Bureau of Statistics. Dhaka. Bangladesh

[26]. Morrison, T. K., \& Sinkin, R. (1982). International Migration in the Dominican Republic: Implications for Development Planning. International Migration Review, 16(4), 819-836.

[27]. Murshid, K., Iqbal, K., \& Ahmed, M. (2002). A study on remittance inflows and utilization. UNDP \& IOM, Dhaka.

[28]. Rahman, M. A., \& Rahman, M. M. (2000). Impact of Migration on Bangladesh Economy: A Critical Analysis. Europe, 727(56.1), 7.7.

[29]. Rahman, M.M. (2000a). Migration as Status Enhancement: A Study of Bangladesh Workers in Singapore. Paper presented at the International Conference on Post Modern Productions: Text-Power and Knowledge, November.

[30]. Rahman, M. M. (2000b). Emigration and development: The case of a Bangladeshi village. International Migration, 38(4), 109-130.

[31]. Rahman, M. M. (2004). Migration and poverty in Bangladesh: Ironies and paradoxes. National University of Singapore.

[32]. Rahman, M. M. (2009). Temporary migration and changing family dynamics: implications for social development. Population, space and place, 15(2), 161-174

[33]. Rahman, M. M. (2013a). Gendering Migrant Remittances: Evidence from Bangladesh and the United Arab Emirates. International Migration, 51(s1), e159-e178.

[34]. Rahman, M. M. (2013b). Migrant Indebtedness: Bangladeshis in the GCC Countries. International Migration.

[35]. Rahman, T. (2013). From Brain Drain to Brain Gain: Leveraging the Academic Diaspora for Development in Bangladesh. Diaspora Engagement and Development in South Asia, 124

[36]. Ratha, D. (2006). Economic Implications of Remittances and Migration: World Bank.

[37]. Roy, A., \& Nangia, P. (2005). Impact of male out-migration on health status of left behind wives--a study of Bihar, India. Paper presented at the meeting of the International Union for the Scientific Study of Population.

[38]. Salim, R. (1992). Overseas remittances in Bangladesh: importance, potentialities and policy options. Jahangirnagar review, Part II, social science XIII and XIV. Jahangirnagar University, Dhaka.

[39]. Sen, A. (1999). Development as freedom: Oxford University Press.

[40]. Siddiqui, T. (2001). Transcending boundaries: Labour migration of women from Bangladesh: University Press.

[41]. Siddiqui, T. (2003). Migration as a livelihood strategy of the poor: the Bangladesh case: Refugee and Migratory Movements Research Unit, Dhaka University.

[42]. Siddiqui, T. (2004). Efficiency of migrant workers' remittance: the Bangladesh case.

[43]. Siddiqui, T. (2004). Institutionalizing Diaspora Linkage. The Emigrant Bangladeshis in UK and USA: International Organisation for Migration, Dhaka.

[44]. Siddiqui, T. (2005). International labour migration from Bangladesh: A decent work perspective. Policy Integration Department Working Paper(66).

[45]. Siddiqui, T., \& Abrar, C. R. (2002). Contribution of returnees: An analytical survey of post return experience: International Organization for Migration, Regional Office for South Asia.

[46]. Siddiqui, T., \& Abrar, C. R. (2003). Migrant worker remittances and micro-finance in Bangladesh. Prepared for Social Finance Programme, Working Paper No. (38). International Labour office, Dhaka

[47]. Siddiqui, T., \& Billah, M. (2012). Labour Migration from Bangladesh 2011: Achievements and Challenges. Dhaka: RMIVIRU and MJF.

[48]. Taylor, E. J. (1999). The new economics of labour migration and the role of remittances in the migration process. International Migration, 37(1), 63-88.

[49]. United Nations Development Programme (2009). HIV vulnerabilities faced by women migrants: from Bangladesh to Arab States].

[50]. United Nations Development Programme (2009). Human Development Report: Overcoming Barriers: Human Mobility and Development. 2009: United Nations Development Programme.

[51]. USAID (2007). Gender consideration in migration and remittances in Bangladesh: Development \& Training Services, Inc. (dTS): Dhaka, Bangladesh.

[52]. World Bank (2013). Global Forum on Remittances 2013. Retrieved 1st June 2014, from http://www.ifad.org/remittances/agenda.pdf 